\title{
Model of Micro Business Development Through Management of Street Vendors Association in Sidoarjo District, East Java
}

\author{
$1^{\text {st }}$ Renny Oktafia \\ Department of Islamic Banking, \\ Faculty of Islamic Religion \\ Universitas Muhammadiyah Sidoarjo \\ renny.oktafia@umsida.ac.id
}

\author{
$2^{\text {nd }}$ Nihlatul Qudus \\ Department of Accounting \\ Faculty of Business, Law and Social \\ Sciences \\ Universitas Muhammadiyah Sidoarjo \\ Indonesia
}

\author{
$3^{\text {rd }}$ Devy Anggraeni \\ Department of Islamic Banking \\ Faculty of Islamic Religion \\ Universitas Muhammadiyah Sidoarjo \\ Indonesia
}

\begin{abstract}
One of the developing countries in the world, whose economic growth has not been too stable is Indonesia. This is due to the fact that large industries still dominate in determining the economic growth of developing countries, even though when an economic crisis occurs, these large industries are the most affected so that it can make its business fall. Therefore, it is necessary to be the focus of policy orientation for developing countries, to encourage the growth of micro businesses, which is actually a strong foundation in maintaining economic stability. Policies in the development of micro-businesses can be done through synergy with the community that fosters these microbusinesses. Based on this description, this study was conducted to explore the activities of the street vendor association and micro business actors, in increasing the capacity of micro businesses in Sidoarjo Regency, East Java. The purpose of this study is to get an overview of the management of the street vendor association and its impact on the development of micro business growth in Sidoarjo Regency, East Java. The method used is qualitative, with a grounded research approach. Data collection techniques are carried out by means of interviews with the management and management of the association, micro business operators who are members of the association, and related service officers. The results of the research obtained are the management of the association starting from providing safe facilities and providing guidance to street vendors and having an impact on increasing the number of street vendors joining the association, dues used as promotional material, relief funds also have a reverse effect. on increasing street vendor income.
\end{abstract}

Keywords-Micro Business, Management, Vendor Association

\section{INTRODUCTION}

Indonesia is a country with a sizeable population in the world, based on the projected population published by Bappenas, Indonesia's population in 2020 will reach 271 million [1]. Conditions like this, of course will cause various problems that will be faced by the government. One of them is how to maintain economic growth, so that it can run stably, and the population can get a decent life.
For this reason, efforts are needed to grow the people's economy, this can be done through encouraging people to create their own businesses. Businesses that have been established by the community, the majority of businesses are micro-scale, or commonly referred to as microbusinesses. Many micro-businesses in Indonesia are also established without having a place to do business, so they carry out their business activities on vacant lots or sidewalks, which are traversed by the general public. The owner of this micro business, popular in Indonesia, is known as a street vendor.

The presence of the traders this time, is a form of effort from the community to create their own jobs, but is not supported by the ability of business owners in the procurement of business land. The existence of this business too, is often associated with social realities, including low income, inadequate education, precarious employment, lack of ability to organize, and other elements of uncertainty. On the other hand, street vendors are also faced with business competition, so they need to increase their solidarity and networks with their fellow men, which can be realized through the association of street vendors [2].

Sidoarjo itself is one of the cities in East Java, which has a fairly large number of micro businesses. According to data from the Office of Cooperatives and SMEs in East Java Province, in 2018 the number of micro small businesses in Sidoarjo is in the range of 248.3 thousand [3]. Therefore, the Sidoarjo district government needs to give good attention to the growth of micro small businesses in Sidoarjo. In Sidoarjo, there are also many micro-businesses in the form of street vendors, and some of them have made associations in maintaining the sustainability of their businesses, so that the Sidoarjo district government can provide support through the established associations.

Based on the description above, this study raises the formulation of the problem, namely how the model of 
micro business development through the management of the street vendor ssociation in Sidoarjo district, East Java.

\section{LITERATURE REVIEW}

A trader is someone who has the activity of buying and selling (transactions) of a product to the buyer (consumer), whether done directly or indirectly [4], Street vendor is a business that requires only a little capital, in the field of production and sales to meet certain consumer needs. Street vendors are usually in places that are considered strategic, such as on the edge of the road, keeping the market street, the sidewalk [5].

One part of the informal sector, which is widely seen and encountered in several developing country cities like Indonesia, is street vendors. The existence of street vendors as an informal sector, which grows in developing countries, is triggered by the socio-economic conditions that occur in developing countries. Thus, this informal sector activity cannot be eliminated, but what is done is to include the informal sector in the formulation of government policies as a consideration and mutual benefit [6].

Street vendors have several characteristics, including: a) In carrying out its activities the pattern of distribution is to occupy public places that are the center of the crowd and do not have a permit, b) have resistance to pressures and control activities, c) as a forum for employment very loose, d) its existence is strongly influenced by the ties of similarity factors of origin, e) on average lacks alternative skills and expertise to set up new businesses outside the informal sector [7].

Street vendors who are part of the micro business group, have a significant contribution to the growth of Gross Domestic Product (GDP). This is because the number of micro business groups is greater than the number of large business groups. However, on the other hand this micro business group, still has low productivity. This low productivity, because there are still obstacles faced by micro business groups, namely the high cost of raw materials, limited capital and marketing difficulties [8].

Besides Indonesia, there is also India which continues to encourage micro businesses in the country, so that they can play an active role in world trade. In India too, it shows that microbusinesses have a significant contribution to GDP, as well as industrial production and exports. However, the most important contribution of microenterprises is to create jobs. Therefore, this micro business sector is targeted to grow $12 \%$ every year [9].

One study was conducted on a culinary micro-business that sells local food in East Nusa Tenggara. In this study, it was also found that the obstacle faced was the lack of collaboration between the government and creative economic institutions in the area, so that micro culinary businesses did not receive guidance to be able to compete in similar industries [10].

To be able to provide guidance, the central government and regional governments can increase the budget, which is related to public services for micro business development. Thus, micro businesses can be more quality and competitive, in the face of increasingly fierce competition [11]. In addition, other research also shows that it is necessary to encourage micro businesses to use their social potential and responsiveness in capturing market opportunities. This can be done through internal structuring aimed at increasing the innovative potential of micro businesses, in producing products in accordance with market demand [12].

\section{METHODS}

This research was conducted in the field to explore data sourced from the location that is concerned with the role of the street vendor community in the development of micro businesses, as a research procedure that produces descriptive data in the form of written or oral words from people and observable behavior. This approach is directed at the background of the individual holistically (intact). So this researcher uses a qualitative research approach [13].

This qualitative research is specifically directed at the use of the Grounded Theory method. Where researchers do not bring ideas as a prior consideration to prove or not. Important issues of participants emerge from the story or story they tell about something that is of interest to the researcher [14].

In conducting this research, one research site was chosen, namely Perkumpulan Pedagang Jalanan Indonesia (Pedalindo) Sidoarjo which is a association of street vendors who have received permission from the Sidoarjo district government. This community, which also has a role in bridging the communication between the local government and all the street vendors it fostered.

\section{RESULTS AND DISCUSSION}

Beginning of the establishment of the pedalindo community in 2015, where before the outbreak of the association, there were many street vendors selling in the Taman Pinang Housing area. This has received rejection from local residents because the activities of street vendors have caused road access to congestion so that the road cannot run smoothly. Therefore, this community was formed to deal with problems that occur due to the activities of street vendors who are less organized, thus disrupting the public interest.

When it was first formed in 2015, the association immediately took care of an official permit and obtained an official permit from the Sidoarjo regency government, so that it was entitled to manage and occupy the Sidoarjo Sports Hall Ponti Street, as a street vendor location. In 2015 , there were only 26 street vendors who joined this association, but in 2019 there was an increase in the number of members to 350 street vendors (interview with the pedalindo management on 30 June 2019), as shown in the table 1 below.

TABLE I. NUMBER OF MEMBERS OF THE INDONESIAN STREET

\begin{tabular}{|c|c|c|}
\hline No & Year & Total \\
\hline 1 & 2015 & 26 \\
\hline 2 & 2016 & 150 \\
\hline 3 & 2017 & 200 \\
\hline 4 & 2018 & 250 \\
\hline 5 & 2019 & 350 \\
\hline
\end{tabular}

Data processed: results of the June 2019 interview 
By continuing to coordinate with the local government, the pedalindo community continues to develop its organization, and continues to provide good guidance and facilities to its members, so that street vendors will get a good name as their capital and also in increasing their business capacity. This, as already stated in the initial purpose of the formation of the community.

The existence of the Pedindo Society has received many positive responses from the public, street vendors and the Sidoarjo regional government. For the surrounding community, with the existence of the pedalindo community which was once a ponti highway is a quiet place, and made a place of crime, now it becomes crowded and safe. In addition, making it easier for the community to shop is also felt by the surrounding community.

For street vendors, members of the association, with the association, can obtain land for sale, which does not violate local government regulations and the public interest. The Circle of Friends also helps street vendors, in increasing sales turnover through promotional efforts to visit and buy the goods of the Circle members. Another thing that is no less important that has been done by the association, namely providing various training to traders, such as online sales training, etc., thus expanding marketing reach, which aims to increase sales turnover because merchants' goods are marketed through various channels both online and offline.

For the regional government, the existence of the association can assist the regional government in fostering and controlling the street vendors, so that the business carried out by the traders can run smoothly, without disrupting community activities. Foot traders can grow, if properly cultivated, thereby opening up jobs, reducing unemployment and ultimately improving the regional economy. If the regional economy grows, it will later increase revenues for local governments, because of the economic turnaround from the sales activities of traders with communities throughout Indonesia and even the world.

Based on the description above, there is a micro business development model through the role of the community, in which in this model collaborates with several related parties, namely: the community, street vendors, and local government, as shown in chart 1 below.

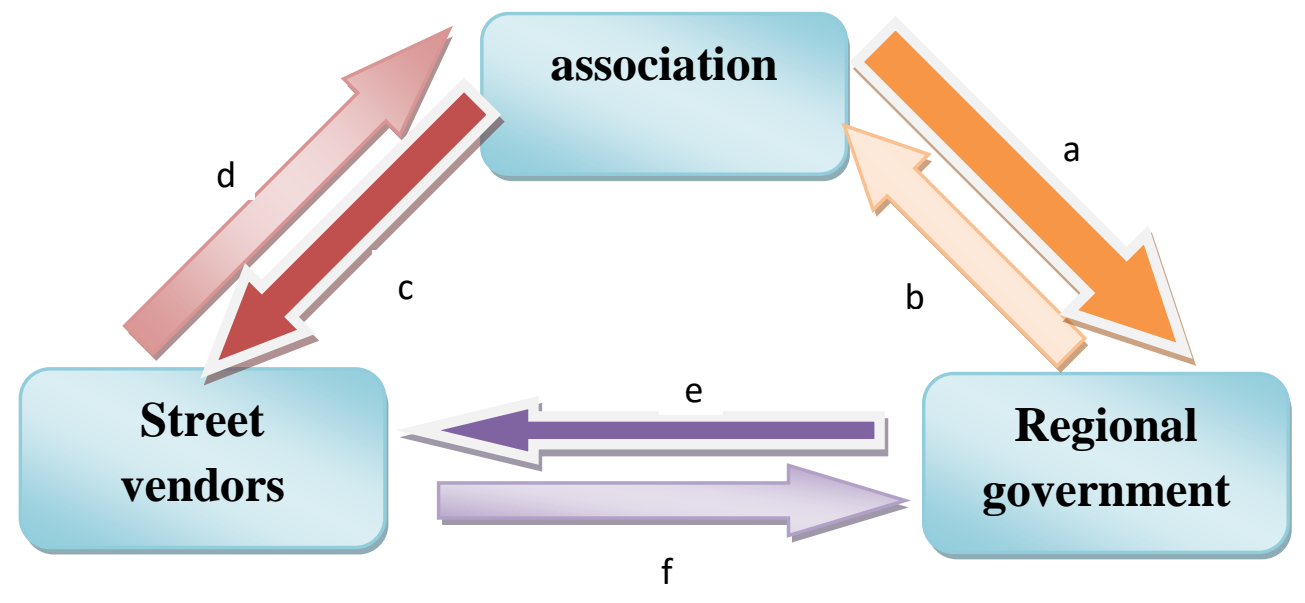

Fig. 1. Micro Business Development Model Through Community Management

Information :

a: Indicates that the community carries out activities in the filing of official permits, reports on the development of community activities and members to the local government. And also as a media connecting communication between traders and the government.

b: Demonstrates that the government gives responsibility for fostering street vendors, monitoring the development of street vendor business through associations making it easier for the government to conduct monitoring rather than having to monitor one by one trader, as well as providing assistance in lending business premises.

c: Show that payuban provides guidance in increasing the business capacity of traders, so that the business can develop.

$\mathrm{d}$ : Indicates that street vendors make financial contributions to the community, which will later return to the merchants, for the purpose of promotion, training, helping each other members in distress, recitation, etc. e: Demonstrates that the local government gives full support to street vendors through the community, to be able to grow and develop.

f: Indicates that the developing street vendors can contribute to local governments in increasing regional economic growth.

\section{CONCLUSION}

The conclusion based on the explanation above states that in this model, collaboration is needed between the parties, namely the community, street vendors and the government, to work together in creating micro business growth. Good community management can synergize micro entrepreneurs with local governments. Thus, street vendors can continue to increase business capacity, which means the business economy can spin and increase its income. On the regional government side, this can later be a stimulus in increasing the regional growth rate. 


\section{REFERENCES}

[1] https://www.bappenas.go.id/files/5413/9148/4109/Proyeksi_Pen duduk_Indonesia_2010-2035.pdf.

[2] Damsar. 2002. Sosiologi Ekonomi (Edisi Revisi).(Jakarta: PT Raja Grafindo Persada)

[3] http://diskopukm.jatimprov.go.id/info/data-ukm.

[4] Sarjono, Yetti. 2015. Pergulatan Pedagang Kaki Lima di Perkotaan. (Surakarta : Muhammadiyah University Press)

[5] Endrawati, Susilo. 2014. "Dampak Relokasi Pasar Studi Kasus Di Pasar Sampangan Kota Semarang" : Serat Acitya. Vol 3, No 1 .

[6] Sumarsono, Sonny. 2009. Teori dan Kebijakan Publik Ekonomi Sumber Daya Manusia. (Yogyakarta : Graha Ilmu)

[7] Suyatno, Bagong dan Kanarji. 2005. Kemiskinan dan Kesenjangan Sosial: Ketika Pembangunan Tak Berpihak Pada rakyat Miskin. (Surabaya : Airlangga University Press)

[8] Tulus T. H. Tambunan. 2011. Development of Micro, Small and Medium Enterprises and Their Constraints: A Story from Indonesia. : Gadjah Mada International Journal of Business, Vol. 13 No. 1

[9] Asghar Afshar Jahanshah, Khaled Nawaser, Seyed Mohammad Sadeq Khaksar, Amin Reza Kamalian. 2011. The Relationship between Government Policy and the Growth of Entrepreneurship in the Micro, Small \& Medium Enterprises of India : Journal of Technology Management, , Vol. 16. Issue 1

[10] Maria C. B. Manteiro, Enos Kabu. 2019. Model of Creative Economic Development for Micro, Small and Medium-sized Culinary Industries in Kupang City Indonesia. International Journal of Social Sciences and Humanities Vol. 3 No. 1, April 2019. No. 1, s.1. : International Journal of Social Sciences and Humanities, 2019, Vol. Vol. 3.

[11] Metasari Kartika. 2019. Public Service and Micro-Small Enterprise Developments in Indonesia.: IJBE (Integrated Journal of Business and Economics), , Vol 3. No 1

[12] Matejun, Marek. 2017. The Effect of Innovative Potential on Small Business Performanc. : PEOPLE: International Journal of Social Sciences,mVol. 3. No.1

[13] Bogdan, Robert C. Dan Steven J. Taylor. 2007. Introduction to Qualitative Research Methotds : A Phenomenological Approach in the Social Sciences (Alih Bahasa). Surabaya: Usaha Nasional)

[14] Morse, Janice M. 2009. Developing grounded theory : the second generation. (New York : Left Coast Press, Inc, ) 